\title{
Biochemical Composition of Different Straw Substrates and Activity of Cellulolytic Enzymes Produced by Pleurotus florida under in vitro Conditions
}

\author{
R.L. Sharma ${ }^{1 *}$ and M.P. Thakur ${ }^{2}$ \\ ${ }^{1}$ Krishi Vigyan Kendra, Raipur, India \\ ${ }^{2}$ Indira Gandhi Krishi Vishwavidyalaya, Raipur 492012 Chhattisgarh, India \\ *Corresponding author
}

\begin{abstract}
A B S T R A C T

\begin{tabular}{|c|}
\hline Keywords \\
\hline $\begin{array}{l}\text { Biochemical composition, } \\
\text { Different straw substrates, Fat } \\
\text { per cent, Carbohydrate } \\
\text { content, Moisture (\%), Protein } \\
\text { content, Pleurotus florida }\end{array}$ \\
\hline Article Info \\
\hline $\begin{array}{l}\text { Accepted: } \\
04 \text { October } 2018 \\
\text { Available Online: } \\
10 \text { November } 2018\end{array}$ \\
\hline
\end{tabular}

The present investigation was undertaken with the objectives to study the biochemical composition of Pleurotus florida grown on different straw substrates and activity of cellulolytic enzymes produced by Pleurotus florida under in vitro conditions. The results revealed that, the biochemical composition of $P$. florida raised on three straw substrates exhibited higher percentage of fat $(2.33 \%)$ on soybean straw followed by wheat $(1.74 \%)$ and paddy straw substrate $(1.65 \%)$ on dry weight basis. The content of carbohydrate in $P$. florida was significantly higher when it was raised on wheat straw substrate $(32.54 \%)$. Moisture (91.68-97.78\%), ash (6.81-7.84\%) and protein (18.30-20.0\%) content of $P$. florida did not vary significantly with the different substrates used. The maximum activity of cellulase was observed in 20 and 16 days old culture filtrate of $P$. florida while, the activity was minimum in 8 days old culture filtrate. Cellulase production was maximum in acidic medium $(\mathrm{pH} 4.0)$ as compared to neutral $(7.0 \mathrm{pH})$ and alkaline $(9.2 \mathrm{pH})$ medium.
\end{abstract}

\section{Introduction}

In India, majority of the people are vegetarian and mushroom became an important source of nutrition in the cereal- based diet. The nutritive value of mushroom varies with the genotype, maturity, substrate, cultivation technology, post-harvest care and processing (Chadha and Sharma, 1995).

It is considered in between fruits and vegetables. It contained $20-30$ percent protein with all essential amino acids (Leucine, lysine and tryptophan) which are deficient in most of the staple cereals and vegetables. Digestibility of mushroom protein is about 60 to 70 percent with digestive coefficient of about 87 per cent. It is an excellent source of folic acid and contains a good amount of vitamin $\mathrm{C}$ and vitamin B complex group (thiamine, riboflavin, niacin) with minerals like calcium, sodium, potassium, iron, copper, zinc, manganese and magnesium). It contains low fat and sugar, which makes them a choice diet for those suffering from diabetic, obesity and hypertension.

The chemical composition of different Pleurotus spp. thus differed with the substrate, time of harvesting, moisture content of the 
substrate and method of assessing the biochemical constituent and hence, it was attempted to study the biochemical constituents as influenced by locally available substrates.

A large number of substrates viz., wheat straw, paddy straw, cotton stalks and various other agro and industrial wastes were evaluated for cultivating different Pleurotus spp. by several workers all over the country (Jandaik, 1974; Bano et al., 1987; Khandar et al., 1991; Mehetre, 1996; Biswas, 1992 and Ram, 1995). But, cereal straw gave consistently good yields. Similarly, various substrates for spawn preparation have been tried but wheat grain spawn was found to be most popular in our country (Chadha and Sharma, 1995). An attempt was further made to evaluate locally and cheaply available substrates for production of spawn as well as crop of $P$. florida in Chhattisgarh. Keeping in view of the above, the present investigation was carried out with the objectives to study the biochemical composition of $P$. florida grown on different straw substrates and activity of cellulolytic enzymes produced by $P$. florida under in vitro conditions.

\section{Materials and Methods}

The research experiments were conducted in the Mushroom Research Laboratory, Department of Plant Pathology, College of Agriculture, Indira Gandhi Krishi Vishwavidyalaya, Raipur and College of Agriculture and Research Station, IGKV, Jagdalpur (C.G.). The pure cultures of Pleurotus spp. used during present experiment were procured from Mushroom Research Laboratory, Department of Plant Pathology, IGAU, Raipur (C.G.). Pleurotus florida was grown on three agrowastes viz., soybean straw, wheat straw and paddy straw. The yield obtained was subjected to chemical analysis for various constituents.
For moisture content estimation, One hundred gram of freshly harvested sporophores were taken and dried in an oven at $60^{\circ} \mathrm{C}$ for 24 hours. It was weighed using electronic balance and again dried in the same way, till the constant weight was obtained. The percentage of moisture was estimated by subtracting the dry weight from the fresh weight of the sporophore.

Moisture $\%=$ Fresh weight of sporophore dry weight of sporophore.

Per cent ash content was determined by the following methods. Fresh mushroom (100 g) was dried and its $1 \mathrm{~g}$ of it was taken in a crucible (silica dish). It was ignited over the flame, first to remove the carbonaceous matter and the remaining burnt mushroom was then ignited in a muffle furnace at about $550^{\circ} \mathrm{C}$, until grey ash formed. Per cent ash content of mushroom was calculated as follows:

Per cent ash content (fresh weight basis) = Weight of crucible with ash (after ignition in furnace) - Weight of empty crucible

For estimation of fat, following procedure was followed. Freshly harvested mushroom (100 g) was dried and $5 \mathrm{~g}$ of material was grinded. A piece of filter paper was folded in such a way that it holds the sample. It was wrapped around a second filter paper which was left open at the top like a thimble. A piece of cotton wool was placed at the top to evenly distribute the solvent as it drops on the sample during extraction. The sample pocket was placed in the butt tubes of the soxhlet extraction apparatus. It was, extracted with petroleum ether (150 drops/minute) for $6 \mathrm{hr}$ without interruption by gentle heating and was allowed to cool and extraction flask was dismantled. The ether was evaporated on a steam or a water bath until, no odour of ether remained. It was cooled at room temperature. The dirt and moisture outside the flask was 
carefully removed and flask was weighed. Heating was repeated until constant weight was achieved. Weight of fat was determined by following formula:

Fat content $=$ Weight of flask with fat Weight of empty flask

For determination of protein content, nitrogen content was first determined. For the same, $1 \mathrm{~g}$ of grinded dry mushroom sample was taken in a digestion tube. $5 \mathrm{~g}$ of digestion mixture $\left(\mathrm{K}_{2} \mathrm{SO}_{4}: \mathrm{CuSO}_{4}\right.$ in 10:1) and $20 \mathrm{ml}$ of $\mathrm{H}_{2} \mathrm{SO}_{4}$ was added in a digestion tube. Boiling chips were dipped and the sample was digested till the solution became green coloured. After cooling the digestion tube, the sample was transferred to a $100 \mathrm{ml}$ volumetric flask and the final volume was made up by distilled ammonia-free water. $10 \mathrm{ml}$ of aliquot was transferred to funnel which reached in distillation flask. A $100 \mathrm{ml}$ conical flask containing $5 \mathrm{ml}$ of boric acid was placed with a few drops of mixed indicator with the tip of the condenser dipping below the surface of the solution. $10 \mathrm{ml}$ of sodium hydroxide- sodium thiosulphate solution was added to the test solution in the apparatus. Distilled and collected the ammonia on boric acid (at least $30 \mathrm{ml}$ of distillate was collected). Tip of the condenser was rinsed and solution was tiltrated against $0.005 \mathrm{~N} \mathrm{H}_{2} \mathrm{SO}_{4}$ until the first appearance of pink colour observed i.e., end point. A blank determination was carried out exactly as mentioned above.

Calculation:

$(\mathrm{V} 2-\mathrm{V} 1) \times \mathrm{M} \times 0.0401 \times 100(\%)$

\% $\mathrm{N}=$ Sample weight $(\mathrm{g})$

Where, $\mathrm{V}_{2}=$ Volume, in $\mathrm{ml}$, of standard $\mathrm{H}_{2} \mathrm{SO}_{4}$ used in titration, $\mathrm{V}_{1}=$ Volume, in $\mathrm{ml}$, of standard $\mathrm{H}_{2} \mathrm{SO}_{4}$ used in blank titration, $\mathrm{M}=$ Molarity of the $\mathrm{H}_{2} \mathrm{SO}_{4}, \%=$ Crude protein = $6.25 \times \% \mathrm{~N}$
For determination of carbohydrate, $500 \mathrm{mg}$ of grinded mushroom sample was taken into a boiling tube. Hydrolysed by keeping it on a boiling water bath for three hours with $5 \mathrm{ml}$ of $2.5 \mathrm{~N}-\mathrm{HCl}$ and cooled to room temperature. It was neutralised with solid sodium carbonate until the effervescence ceased. Volume was made upto $100 \mathrm{ml}$ and centrifuged. Collected the supernatent and took 0.5 and $1 \mathrm{ml}$ aliquat for analysis. The standards were prepared by taking $0,0.2,0.4,0.6,0.8$ and $1 \mathrm{ml}$ of the working standard. O' served as blank. The volume was made upto $1 \mathrm{ml}$ in all the tubes including the sample tubes by adding distilled water. Then, $4 \mathrm{ml}$ of anthrone reagent was added. Heated for eight minutes in a boiling water bath. Cooled rapidly and read the green to dark green colour at $630 \mathrm{~nm}$. A standard graph was drawn by plotting concentration of the standard curve on the $\mathrm{x}$-axis versus absorbance on the y-axis. From the graph, the amount of carbohydrate present in the sample tube was calculated.

Calculation:

[mg of glucose / Volume of test sample] x 100

Cellulase activity was determined by measuring the reduction in viscosity of 0.5 per cent carboxymethyl cellulose (Muse et al., 1972). Viscometric measurements were made with Ostwald's viscometer at time intervals of $0,1 / 2,1,2,3,4,5,6$ and $7 \mathrm{hrs}$. The reaction mixture consisted of $5.0 \mathrm{ml}$. of 0.5 per cent carboxymethyl cellulose solution. $2.0 \mathrm{ml}$. of sodium citrate buffer at $\mathrm{pH}$ levels of 4,7 and 9.2 adjusted with the help of buffer tablets and $2.0 \mathrm{ml}$. of enzyme preparation. The reduction in viscosity for $\mathrm{CMC}$ was calculated by the following formula:

Per cent loss in viscosity $=\frac{T_{0}-T_{1}}{T_{0}-T_{w}} \times 100$

Where, $\mathrm{T}_{0}=$ Flow time of reaction mixture at " 0 " minute and $\mathrm{T}_{1}=$ Flow time of reaction at a particular time interval. 


\section{Results and Discussion}

\section{Chemical composition of $\boldsymbol{P}$. florida on three straw substrate}

Pleurotus florida raised on three straw substrates was analysed for varying chemical constituents present and the results are presented in Table 1. Among different chemical constituents analysed, fat and carbohydrate content (on dry weight basis) of $P$. florida was found to differ significantly on three straw substrate. Pleurotus florida produced on soybean straw substrate gave significantly higher percentage of fat $(2.33 \%)$ followed by wheat straw substrate $(1.74 \%)$ and paddy straw substrates $(1.65 \%)$. Similarly, carbohydrate content of $P$. florida was more on wheat straw substrate $(32.54 \%)$ followed by paddy straw substrate $(20.0 \%)$ and soybean straw substrate $(18.30 \%)$.

On the other hand, moisture, ash and protein content of $P$. florida did not differ significantly when grown on different straw substrates. However, the content of moisture vary from 91.68 to 91.78 percent, ash from 6.81 to 7.84 and protein from 18.30 to 20.00 per cent.

\section{Activity of cellulolytic enzymes produced by Pleurotus florida}

The activities of cellulolytic enzymes produced by Pleurotus florida was assessed under in vitro conditions by measuring the loss in viscosity per cent and the results are presented in Table 2.

Table.1 Chemical composition of Pleurotus florida on three straw substrates

\begin{tabular}{|l|c|c|c|c|c|}
\hline \multicolumn{1}{|c|}{ Substrates } & $\begin{array}{c}\text { Moisture } \\
(\mathbf{\%})\end{array}$ & $\begin{array}{c}\text { Ash } \\
(\boldsymbol{\%})\end{array}$ & $\begin{array}{c}\text { Protein } \\
(\mathbf{\%})\end{array}$ & $\begin{array}{c}\text { Carbohydrate } \\
(\boldsymbol{\%})\end{array}$ & $\begin{array}{c}\text { Fat } \\
(\mathbf{\%})\end{array}$ \\
\hline Soybean straw & 91.78 & 7.84 & 19.21 & 19.97 & 2.33 \\
\hline Wheat straw & 91.70 & 6.81 & 18.30 & 32.54 & 1.74 \\
\hline Paddy straw & 91.68 & 7.20 & 20.00 & 26.71 & 1.65 \\
\hline SEm \pm & $\mathbf{1 . 7 0}$ & $\mathbf{0 . 9 8}$ & $\mathbf{0 . 8 7}$ & $\mathbf{0 . 4 9}$ & $\mathbf{0 . 0 1}$ \\
\hline CD $(\mathbf{0 . 0 5 \% )}$ & NS & NS & NS & $\mathbf{1 . 5 6}$ & $\mathbf{0 . 0 3}$ \\
\hline
\end{tabular}

Table.2 Influence of culture filtrate of Pleurotus florida on the activity of $\mathrm{CMC}$ at different $\mathrm{pH}$ level

\begin{tabular}{|c|c|c|c|c|c|c|c|c|c|c|c|c|}
\hline \multirow{2}{*}{$\begin{array}{c}\text { Time of } \\
\text { interval In hrs }\end{array}$} & \multicolumn{3}{|c|}{8 days old } & \multicolumn{3}{|c|}{12 days old } & \multicolumn{3}{|c|}{16 days old } & \multicolumn{3}{|c|}{20 days old } \\
\hline & 4.0 & 7.0 & 9.2 & 4.0 & 7.0 & 9.2 & 4.0 & 7.0 & 9.2 & 4.0 & 7.0 & 9.2 \\
\hline 0.0 & 0.0 & 0.0 & 0.0 & 0.0 & 0.0 & 0.0 & 0.0 & 0.0 & 0.0 & 0.0 & 0.0 & 0.0 \\
\hline 0.3 & 6.10 & 5.21 & 4.11 & 3.24 & 3.12 & 6.37 & 4.21 & 4.06 & 7.14 & 7.15 & 9.20 & 7.42 \\
\hline 1.0 & 13.46 & 11.23 & 8.14 & 10.42 & 12.67 & 8.90 & 8.86 & 16.45 & 9.64 & 11.23 & 19.54 & 13.22 \\
\hline 2.0 & 24.31 & 6.23 & 16.27 & 14.34 & 19.20 & 14.78 & 15.72 & 13.71 & 22.25 & 24.26 & 24.26 & 25.43 \\
\hline 3.0 & 32.26 & 9.85 & 23.46 & 16.27 & 22.31 & 18.24 & 21.45 & 20.25 & 26.28 & 39.16 & 28.42 & 30.64 \\
\hline 4.0 & 36.02 & 14.25 & 22.27 & 21.45 & 29.52 & 20.29 & 39.24 & 23.08 & 29.41 & 46.50 & 32.03 & 37.16 \\
\hline 5.0 & 39.50 & 18.34 & 26.21 & 27.36 & 30.24 & 24.28 & 42.62 & 28.45 & 31.29 & 50.14 & 34.16 & 40.23 \\
\hline 6.0 & 41.06 & 24.23 & 29.33 & 32.24 & 33.26 & 30.12 & 44.02 & 33.56 & 34.20 & 53.62 & 36.28 & 44.41 \\
\hline 7.0 & 41.06 & 24.23 & 29.33 & 32.24 & 33.26 & 30.12 & 44.02 & 33.56 & 34.20 & 53.62 & 36.28 & 44.41 \\
\hline SEm \pm & 0.95 & 0.86 & 0.82 & 0.85 & 1.01 & 0.86 & 0.85 & 0.87 & 0.87 & 0.86 & 0.86 & 0.85 \\
\hline CD $(0.05 \%)$ & 2.76 & 2.49 & 2.38 & 2.47 & 2.92 & 2.50 & 2.48 & 2.51 & 2.52 & 2.49 & 2.49 & 2.47 \\
\hline
\end{tabular}


The maximum activity of cellulase was observed in 20 and 16 days old culture filtrate of Pleurotus florida while, the activity was minimum in 8 days old culture filtrate. Cellulase enzyme production was maximum in acidic medium $(\mathrm{pH} 4.0)$ as compared to neutral (7.0) and alkaline (9.2) medium. In general, the per cent loss in viscosity was gradually increased with increase in the time interval and age of culture filtrate under test.

The biochemical composition of $P$. florida raised on three straw substrates exhibited higher percentage of fat $(2.33 \%)$ on soybean straw followed by wheat $(1.74 \%)$ and paddy straw substrate $(1.65 \%)$ on dry weight basis. The present study corroborates with the results of Bano and Rajarathnam (1982) and Chelawat and Choudhary (1994) who reported fat content of 2.5 to 2.85 per cent in Pleurotus spp. on dry weight basis.

The content of carbohydrate in P. florida was significantly higher when it was raised on wheat straw substrate (32.54\%). The findings of Bano and Rajarathnam (1982) showed little higher content of carbohydrate varying from 46.6 to 81.6 per cent in different species of Pleurotus.

The present findings contradict the findings of Pathak (1917) who reported 47.68 per cent of carbohydrate in $P$. sajor-caju which was raised on paddy straw substrate. Lower content of carbohydrate (19.97 to $32.54 \%$ ) in $P$. florida during present study may be associated with the inherent characteristic of the species itself. However, further studies need to be confirmed. Moisture (91.68$97.78 \%)$. ash (6.81-7.84\%) and protein (18.30-20.0\%) content of P. florida did not vary significantly with the different substrate used. These contents were well compared with other species of Pleurotus reported by several workers (Crisan and Sands, 1978; Bano and Rajarathnam, 1982; Sivaprakasam,
1980; Bano et al., 1979; Sethi and Anand, 1984; Rai and Sohi, 1988; Ram, 1995; Banik, 1996; Kumar and Kumar, 1997; Pathak, 1997 and Chelawat and Choudhary, 1994).

The maximum actively of cellulase was observed in 20 and 16 days old culture filtrate of Pleurotus florida while, the activity was minimum in 8 days old culture filtrate. Geetha et al., (1998) also reported higher activity of enzyme production after 20 days of inoculation of $P$. djamor and $P$. citrinopileatus. In the present study, cellulase production was maximum in acidic medium at $\mathrm{pH} 4.0$ as compared to neutral $(7.0 \mathrm{pH})$ and alkaline $(9.2 \mathrm{pH})$ medium.

\section{References}

Banik, P. 1986. Mushroom: the cheapest source of protein. Indian Farm, (2): 2829.

Bano, Z. and Rajarathnam, S. 1982. Studies on the cultivation of Pleurotus sajorcaju. Mush. J. 115: 243-245.

Bano, Z., Rajarathnam, S. and Nagaraja, N. 1987. Some important studies of Pleurotus mushroom technology. Indian Mush. Sci. 12 (2): 67-71.

Biswas, M. K. 1992. Exploring of methods for increasing of biological efficiency of oyster mushroom (Pleurotus florida). M. Sc. Thesis submitted to IGAU, Raipur. P. 66.

Chadha, K. L. and Sharma, S.R. 1995. Mushroom research in India-History, infrastructure and achievements. In: "Advance in Horticulture, Vol. 13. Mushroom" (Eds. K.L. Chadha and S.R. Sharma), Malhotra Publishing House, New Delhi, pp. 1-33.

Chelawat, Shilpa and Maya, Choudhary 1994. Composition of Pleurotus mushroom. Paper presented in National symposium on mushroom held at NCMRT, Solan, pp. 9. 
Crisan, E.V. and Sands, A. 1978. Nutritional value of edible mushroom. In: the Biology and cultivation of edible mushroom (Eds. S.T. Chang and W.A. Hays). Academic Press, New York. Pp.137-168.

Geetha, D. and Sivaprakasam, K. 1998. Enzyme production and sporophore production potential of oyster mushroom (Pleurotus spp.). Mushr. Res. 7(1): 39-42

Jandaik, C. L. 1974. Artificial cultivation of Pleurotus sajor-caju. Mush. J. 22:405.

Khandar, R. R., Vaishnav, M. V., Akbari, L. F., and Andhania, J. H. 1991. Effect of various plant substrates on Sporophore production of Pleurotus sajor-caju. Indian mushrooms proceedings of National symposium on mushrooms. Tiruvananthapuram, 112-113.

Kumar, Sunil and Kumar, S. 1997. Mushroom delicacies. Indian Hort. 49(4): 59-60.

Mehetre, S. S., Dhumal, P. M., Shinde, R. B., Kale, K. D. and Magdum, S. G. 1996. Soybean straw and agrowaste best for mushroom cultivation. Indian Farm, July: 20-21.

Muse, R.R., Couch, H.B., Moore, L.D. and Muse, B.D. 1972. Pectinolytic and cellulolytic enzyme associated with Helminthosporium leaf spot of kentachy blus grass. Can. J. Microbial 18: 10911098.

Pathak, Moni 1997. Effect of different substrates on biochemical compositions of the fruit bodies in edible mushroom (Pleurotus sajor-caju). Paper presented in Indian Mushroom Conference-97 at NCMRT, Solan from $10-13^{\text {th }}$ September, pp. 69.

Rai, R. D. and H. S. Sohi 1988. How protein rich are mushroom. Indian Hort, 33(2): 2-3.

Ram, R. N. 1995. Studies on oyster mushroom (Pleurotus florida) and mycoflora associated with paddy straw substrate, M.Sc. Thesis submitted to IGAU, Raipur. 97.

Sethi, Vijay and Anand, J. C. 1984. Nutritional quality of fresh and processed mushroom. Indian Hort. 29(3): 7-8.

Sivaprakasam, K. 1980. Studies on oyster mushroom (Pleurotus sajor-caju) Ph.D. Thesis submitted to Tamilnadu Agril. Uni., Coimbatore.pp.158.

\section{How to cite this article:}

Sharma, R.L. and Thakur, M.P. 2018. Biochemical Composition of Different Straw Substrates and Activity of Cellulolytic Enzymes Produced by Pleurotus florida under in vitro Conditions. Int.J.Curr.Microbiol.App.Sci. 7(11): 315-320. doi: https://doi.org/10.20546/ijcmas.2018.711.039 